NBER WORKING PAPER SERIES

\author{
MISREPORTING TRADE: \\ TARIFF EVASION, CORRUPTION, AND AUDITING STANDARDS \\ Derek Kellenberg \\ Arik Levinson \\ Working Paper 22593 \\ http://www.nber.org/papers/w22593
}

\author{
NATIONAL BUREAU OF ECONOMIC RESEARCH \\ 1050 Massachusetts Avenue \\ Cambridge, MA 02138 \\ September 2016
}

The authors are grateful to Jordan Marcusse for research assistance, and to the National Science Foundation (grant \#1156170). The views expressed herein are those of the authors and do not necessarily reflect the views of the National Bureau of Economic Research.

NBER working papers are circulated for discussion and comment purposes. They have not been peer-reviewed or been subject to the review by the NBER Board of Directors that accompanies official NBER publications.

(C) 2016 by Derek Kellenberg and Arik Levinson. All rights reserved. Short sections of text, not to exceed two paragraphs, may be quoted without explicit permission provided that full credit, including $(\odot$ notice, is given to the source. 
Misreporting Trade: Tariff Evasion, Corruption, and Auditing Standards

Derek Kellenberg and Arik Levinson

NBER Working Paper No. 22593

September 2016

JEL No. F14

\begin{abstract}
$\underline{\text { ABSTRACT }}$
In official international trade statistics, annual commerce between every pair of countries is reported twice: once by the importing country and once by the exporter. These double reports provide an opportunity for audit. In principle, the two reported trade values should differ systematically only by transport costs, because the values reported by importers include freight and insurance. But in practice, after controlling for distance and other standard trade costs, the remaining gaps between importer- and exporter-reported trade vary systematically with GDP, tariffs and taxes, auditing standards, corruption, and trade agreements, suggesting that firms intentionally misreport trade data. These misreports have implications for trade agreements and domestic fiscal policy, and for empirical assessments of the efficacy of those policies.
\end{abstract}

Derek Kellenberg

Economics Department

University of Montana

32 Campus Dr. \#5472

Missoula, MT 59812-5472

derek.kellenberg@mso.umt.edu

Arik Levinson

Department of Economics ICC 571

Georgetown University

3700 O St., NW

Washington, DC 20057

and NBER

aml6@georgetown.edu 


\section{Misreporting Trade: Tariff Evasion, Corruption, and Auditing Standards}

\section{Introduction}

News stories about misreported trade periodically surface in the business press. In 2012 Chinese customs officials detained 50 people for underreporting seafood imports and evading $\$ 11.6$ million in tariffs. ${ }^{1}$ In 2014 Mexican authorities disrupted a tariff evasion ring that involved 22 customs officers and 197 companies around the world and had cost Mexico \$37 million in unpaid tariffs. ${ }^{2}$ And later that same year, Pakistani investigators caught customs officials plotting with an importer to underreport the value of 110 containers of textiles. ${ }^{3}$ Common themes in these stories include tariff and tax evasion, corruption, regulatory enforcement, and firms and organizations spanning countries at different levels of economic development. In this paper we show that this type of trade misreporting is widespread and varies systematically with country characteristics such as economic development, taxes and tariffs, corruption, and participation in regional trade agreements (RTAs).

The importance of tariff evasion has not gone unnoticed by economists. Fisman and Wei (2004) examined the effect of tariff rates on reported trade between China and Hong Kong. Subsequent papers have applied their approach to other groups of countries: exports from Germany to 10 transition economies, imports to India, direct exports from China to the United States, trade between the United States and Canada, imports to Kenya, Mauritius, and Nigeria, and most recently, Tanzanian imports from three developing country trading partners. ${ }^{4}$ And although global assessments are scarce, one recent study estimated that in 2012, more than \$729 billion flowed out of developing countries as the result of trade misinvoicing and tariff evasion (Kar and Spanjers 2014).

Such reports mostly confirm the Fisman and Wei result that higher tariff rates lead to more tariff evasion for the samples of countries studied. Like Fisman and Wei, they all identify evasion by comparing reported product-level tariffs with product-level trade data reported by exporters and importers between select pairs of countries. As a result, even though the combined

\footnotetext{
${ }_{1}^{1}$ www.seafoodsource.com/news/supply-trade/19001-chinese-authorities-arrest-50-for-tariff-evasion.

2 latino.foxnews.com/latino/news/2014/10/23/mexico-dismantles-textile-industry-tariff-evasion-ring.

3 tribune.com.pk/story/801951/tariff-evasion-customs-seize-dry-port-records-to-probe-rs170-million-scam.

4 See Javorcik and Narciso (2008), Mishra et al. (2008), Ferrantino et al. (2012), Stoyanov (2012), Bouët and Roy (2012), and Epaphra (2015).
} 
body of evidence suggests that higher tariffs lead to more misreporting, the results are not generalizable beyond the specific sets of countries examined. We don't really know the extent to which trade misreporting occurs across a broader set of countries or goods, whether it has been increasing over time, or whether it is more prevalent among rich or poor countries.

More importantly, the focus on tariff evasion disregards other country characteristics that may reward or penalize firms for misreporting trade. Many of these, like income taxes, corruption, accounting standards, and capital controls, do not vary across industries within a country but do vary across countries and over time. So their effects on misreported trade cannot be identified using isolated pairs of countries. A large panel of trade data and country characteristics, like the one we have assembled for this project, is necessary to identify the effects of these country characteristics on misreported trade.

We begin by describing a model in which firms choose how much to misreport their imports or exports. Those misreports are functions of country characteristics like tariffs, corruption, taxes, and the strength of auditing and accounting standards. We then use that model, along with a simple accounting identity, to estimate the effects of those country characteristics on the gap between total reported exports and imports among pairs of countries, using data on annual trade among 126 countries from 2002 to 2012.

Our approach using aggregate trade, as opposed to the industry-by-industry measures used by Fisman and Wei (2004) and others, does come with a trade-off. The aggregate approach cannot identify trade misreporting that results from misclassifying products, say from high-tariff to low-tariff categories, because those misreports are netted out in the aggregate. ${ }^{5}$ What we observe is pure misreporting: cases where firms have reported to trade authorities a value different from the true value transacted. In this sense, our analysis should be viewed as a conservative estimate of overall trade misreporting.

In return, however, our aggregated approach has several advantages. First, by examining aggregate trade among many countries, we are able to estimate the effects of policy-relevant

\footnotetext{
${ }^{5}$ For example, suppose metal chairs are being traded but wooden chairs have a lower tariff rate. An exporter may correctly report $\$ 100,000$ in metal chairs to the exporting country while the importer reports $\$ 100,000$ in wooden chairs to the importing country to evade the higher tariff. This would be an example of tariff evasion through misclassification. But in aggregate, the misreported value would be zero. Both countries have reported \$100,000 in chairs. If instead the importer reported $\$ 50,000$ worth of chairs (metal or wooden), then the aggregate misreported trade gap would be $\$ 50,000$.
} 
country characteristics other than tariffs. These include auditing and accounting standards, ${ }^{6}$ corruption, participation in RTAs, and other domestic tax rates. Second, by netting out misclassification through aggregation and focusing on pure misreporting effects, we avoid difficult empirical challenges associated with disentangling the two in industry-level analyses. Third, when we do examine tariffs, our estimation strategy allows us to estimate their average effect on misreporting across a wide variety of importing and exporting countries. And finally, by aggregating across industries and using country variables as proxies for misreports, we account for the potential endogeneity of true unobserved trade volumes and those misreports.

Based on a 126-country, 11-year panel, our empirical results confirm prior findings that tariffs lead to underreporting of imports. We show, however, that the results are not uniform across countries. For pairs of countries that are both RTA members, with correspondingly low or zero tariffs, the measured tariff elasticity of misreporting is zero, as would be expected. For country pairs that are not RTA members, the tariff elasticity of misreporting is large, and it is larger for high-income countries than for low-income countries. A 1 percent increase in average tariff rates leads to a 3 percent increase in relative underreporting by high-income importers but a 1 percent increase in relative underreporting by low-income importers.

As for the country characteristics other than tariffs, we find robust evidence that stronger auditing and accounting standards decrease the underreporting of exports (relative those same shipments reported by importers). A one standard deviation increase in an index of those standards in the exporting country decreases the trade gap by approximately 3.8 percent. This finding is consistent across both high- and low-income countries and underscores the importance and economic benefits of strong auditing and accounting standards. We also find that corruption plays an important role in the degree of misreports for both importers and exporters. A one standard deviation decrease in an index of exporter corruption corresponds with a 12.5 percent decrease in the reported trade gap in both high- and low-income countries. Corruption is also associated with more underreporting of imports by low-income countries. Finally, we find some evidence that higher domestic tax rates correspond to more underreported trade by exporting countries.

\footnotetext{
${ }^{6}$ A few papers, such as Javorcik and Narciso (2008) and Mishra et al. (2008), find evidence of greater tariff evasion in product categories that are more differentiated and therefore harder for customs officials to enforce. However, the method only indirectly measures enforcement and has only been applied to select product categories and countries.
} 
These results are important for two reasons. First, tariff revenue remains an important source of funds for many governments, particularly in developing nations. Revenues lost to tariff evasion result in lower government services or higher taxes on capital or labor income (Kim and Kose 2014) and can result in higher international aid to developing countries (Collier and Venables 2011). In general, understanding how tariffs, corruption, and auditing standards affect misreporting can aid and improve enforcement and tariff revenue collection.

Second, although recent research suggests that corruption affects the real value of trade, ${ }^{7}$ we show that corruption increases the misreporting of that trade. So some of corruption's effect on trade measured previously may be attributable to increased misreporting, not real trade reductions. Similarly, regarding the trade creation and diversion effects of RTAs, ${ }^{8}$ our results find substantially more misreporting among non-RTA members than among RTA members. So some of the "trade creation" measured by prior work may be attributable to less underreporting.

Before outlining our firm-level theory of trade misreporting, in the next section we describe some aggregate statistics that motivate the analysis.

\section{A Snapshot of Trade Misreports}

In the UN Comtrade data, which contain annual industry-level trade flows among countries, each annual value is collected and reported twice-once by the exporting country and once by the importing country. ${ }^{9}$ This project is motivated by the fact that the two values appear to differ, significantly and systematically.

Figure 1 plots the sum of all global trade as reported by importers and exporters separately. ${ }^{10}$ Total trade reported by importers is larger, as expected, because the importer reports include cost, insurance, and freight (CIF) transport costs. But the difference is tiny, suggesting little aggregate misreporting. It turns out, however, that the global aggregates mask a lot of cross-country heterogeneity.

To examine the difference between the trade reported by importers and exporters in more detail and as a proportion of total reported trade, define the "trade reporting gap” as

\footnotetext{
${ }^{7}$ See Dutt and Traca (2010) or Thede and Gustafson (2012).

${ }^{8}$ Examples include Magee (2008) and Carrére (2006).

${ }^{9}$ The Comtrade data can be found at http://comtrade.un.org/db/.

10 Trade data are available for more years than we examine here, but our analysis in later sections is limited to 20022012 by the availability of data on some country characteristics, such as accounting and auditing standards and organized crime.
} 


$$
\text { trade reporting gap }=\frac{V_{x m}^{m}-V_{x m}^{x}}{V_{x m}^{m}+V_{x m}^{x}} .
$$

where $V_{x m}^{m}$ is the annual total trade shipped from exporting country $x$ to importing country $m$, as reported by the importer $(m)$, and $V_{x m}^{x}$ is that exact same annual value, as reported by the exporter $(x)$. Subscripts denote the exporting and importing countries; superscripts denote the reporting country. The trade gap in (1) can in theory range from -1 to +1 , but in practice $V_{x m}^{m}$ and $V_{x m}^{x}$ should differ only by CIF trade costs, and so the trade reporting gap should be small and never negative.

Figure 2 plots a histogram of the annual values of equation (1). Each observation is the annual gap between two countries, and each pair of countries appears twice each year: once for exports from $x$ to $m$, and once for the reverse. The mean and mode of the observations are clustered slightly above zero, as already demonstrated by Figure 1 and as expected by the importer reports' inclusion of CIF trade costs. But the spread is remarkable. For a significant fraction of the annual observations, the importer reports are more than twice or less than half of the exporter reports. ${ }^{11}$ In fact, rather than declining continuously farther from zero, the number of observations with trade gaps outside \pm 0.75 is increasing. When the gap is 0.75 , reported imports are seven times as large as exports. Clearly, there are lots of enormous, orders-ofmagnitude differences between the two reports. ${ }^{12}$ Our goal in this project is first to examine whether those trade gaps are all merely accidental reporting errors or whether some represent intential misreports by importers or exporters seeking to avoid taxes or tariffs, and then to examine the role that corruption, accounting standards, economic development, and trade agreements play in exacerbating or eliminating the degree of miseports.

If trade reporting gaps arise from intentional misreports, a natural motive is tariff evasion. Figure 3 plots the trade gap in 10 deciles organized by the size of the average tariff on those trades. Surprisingly, the trade gap grows for the first four deciles. Reported imports (which must pay the tariff) exceed reported exports by more the higher the tariff. Less surprisingly, for the highest six deciles of the tariff, as tariffs increase, reported imports shrink relative to reported exports. That hump-shaped pattern may arise from two offsetting forces. The higher the tariffs,

\footnotetext{
${ }^{11}$ When this happens, the trade gap is outside $\pm 1 / 3$.

${ }^{12}$ In what follows we test several subsamples of our data in which we exclude cases where reported exports exceed reported imports by orders of magnitude, and vice versa.
} 
the more incentive the importing country has to enforce accurate reporting, and the more incentive the importer has to underreport imports. In what follows we try to account for this by controlling for accounting and auditing standards along with tariffs.

Figure 4 presents some evidence that the misreports are correlated with these other country characteristics. Each panel in Figure 4 plots the average trade reporting gap by quintile of a different characteristic of the exporting country. For example, the upper left graph in Figure 4 shows that when exporters' auditing standards are rated more highly by the World Economic Forum, the trade reporting gap is lower. ${ }^{13}$ Since that gap is the importer report minus the exporter report, we interpret the pattern in Figure 4 as indicating that exporters from well-audited countries are less likely to underreport (as opposed to importers from well-audited countries being less likely to overreport, which is mathematically possible but makes less intuitive sense). Similarly, in the upper right graph in Figure 4, exporters from countries with more corruption are more likely to underreport. And in the bottom two graphs, exporters from poorer countries underreport more, and exporters from high tax countries underreport less, though that latter pattern may be nonmonotonic for reasons similar to tariffs in Figure 3.

Figure 5 plots the same four figures by importer characteristics, displaying some of the same trends, though the patterns are less stark. And clearly, none of this is anything but suggestive. Tariffs are correlated with GDP. Both are likely correlated with corruption, accounting standards, and other country characteristics that affect trade misreports, and all of those country characteristics have been changing over time. To study how trade reporting responds to country characteristics more systematically, we need an empirical model that embodies the incentives for firms to misreport their imports and exports.

\section{A Firm-Level Model of Trade Misreporting}

Our starting point is a generalized version of the model in Ferrantino et al. (2012). In each industry $i$ and year $t$ there is a representative exporting firm in country $x$ and a representative importing firm in country $m$. The firms privately negotiate and know the true value of free-on-board (FOB) exports, $V_{x m i t}^{*}$, but this value is not known by customs officials, as signified by the superscript asterisk (*). This FOB value is the true value of goods when they

\footnotetext{
${ }^{13}$ http://reports.weforum.org/global-competitiveness-report-2015-2016/.
} 
arrive at the exporting port before shipping to the importing country. ${ }^{14}$ We make no assumption about the underlying market structures, competitive or otherwise. We simply assume that each firm chooses prices and quantities to maximize profits given the market structure and competition they face, resulting in a privately negotiated equilibrium value for (unobserved) $V_{x m i t}^{*}$.

Each exporting firm has to decide how much of its exports to report to authorities, $V_{x m i t}^{x}$. Let $\delta^{x}$ be the proportional deviation from the true value $V^{*}$ that the exporter reports: $V_{x m i t}^{x}=(1+\delta) V_{x m i t}^{*}$. The superscript $x$ denotes that $\delta^{x}$ is the exporter's deviation. Firms may choose to underreport exports $\left(\delta^{x}<0\right)$, report accurately $\left(\delta^{x}=0\right)$, or overreport $\left(\delta^{x}>0\right)$. These deviations may come in the form of misreporting prices (as with transfer pricing) or quantities. ${ }^{15}$

Why would firms misreport exports? Doing so has both costs and benefits. First, firms may incur product, sales, or service taxes or subsidies on the proceeds of goods exported, giving them incentives to under- or overreport those exports. Second, in an effort to stabilize currency and capital accounts, some countries restrict capital exports or imports (Prasad and Rajan 2008). To evade those capital controls, firms may misreport trade transactions (Patnaik et al. 2012). Third, firms in countries with more corruption or organized crime may have to pay bribes or face extortion if they misreport the true value of exported goods (Dutt and Traca 2010). Finally, firms in countries with stricter accounting and auditing standards may have a harder time misreporting trade.

Each of these motivations can be represented by a function representing the net benefit of misreporting:

$$
B^{x}=B^{x}\left(\delta^{x}, V_{x m}^{*}: \mathbf{Z}_{x m}^{x}\right)
$$

where the industry and year subscripts are suppressed. The benefit (or cost) of misreporting exports is a function of the size of the misreport $\delta^{x}$ and the true value of exports $V^{*}$, both of which are chosen by the exporting firm, and a set of country characteristics $\mathbf{Z}$. These include

\footnotetext{
${ }^{14}$ For now, we just assume that these trades are negotiated in US dollars. The Comtrade data we use are typically reported in national currencies and then converted to dollars by the UN using average annual trade-weighted exchange rates.

${ }^{15}$ Ferrantino et al. (2012) assume that the quantity of trade $q$ is fixed and that the two firms negotiate over price $p$. Either way, in the next step we take this market-determined value, $V=p \times q$, as given and model the reduced form decision about what fraction of that $V$ to misreport. In our model, it does not matter whether $\delta^{x}$ multiplies $p$ or $q$ as it has the same effect on $V$.
} 
taxes, capital controls, auditing standards, and levels of corruption. For any given value of true exports, $V^{*}$, firms choose misreporting $\delta^{x}$ to maximize (2), resulting in an implicit function:

$$
\delta^{x}=\delta^{x}\left(V_{x m}^{*}: \mathbf{Z}_{x m}^{x}\right)
$$

On the importing side, firms face all the same benefits and costs of misreporting as exporters plus one important additional incentive: tariffs, $\tau^{m}$. As with exports, we can think of importers' choosing true imports $V^{*}$ and misreports $\delta^{m}$ to maximize the net benefit (or cost) of misreporting:

$$
B^{m}=B^{m}\left(\delta^{m}, V_{x m}^{*}: \tau_{x m}^{m}, \mathbf{Z}_{x m}^{m}\right)
$$

And as with exports, for a given true value of trade, this defines an implicit function for optimal misreported imports:

$$
\delta^{m}=\delta^{m}\left(V_{x m}^{*}: \tau_{x m}^{m}, \mathbf{Z}_{x m}^{m}\right)
$$

Obviously we cannot estimate (3) or (5) directly. We don’t observe the true value of trade $V_{x m}^{*}$ or the misreports $\delta^{x}$ and $\delta^{m}$. But we can use the country characteristics in $\mathbf{Z}$ as proxy variables to estimate the effects of those characteristics on aggregate trade misreporting. So the next step is to convert (3) and (5) into equations that can be estimated, which we do using a simple accounting relationship between reported trade and the unobserved true value of trade.

Observable reported exports $V_{x m i t}^{x}$ in any industry $(i)$ and year $(t)$ must be equal to the true unobservable trade value times the exporter's misreport and a random error term $\left(\varepsilon_{x m i t}^{x}\right)$, which we assume to be multiplicative and lognormally distributed.

$$
V_{x m i t}^{x}=V_{x m i t}^{*}\left(1+\delta_{x m i t}^{x}\right) \varepsilon_{x m i t}^{x}
$$

Similarly, reported imports $V_{x m i t}^{m}$ must equal the true trade value, adjusted for misreports, an error term, and CIF trade costs $\sigma_{x m i t}>1$ that we assume are also multiplicative.

$$
V_{x m i t}^{m}=V_{x m i t}^{*} \sigma_{x m i t}\left(1+\delta_{x m i t}^{m}\right) \varepsilon_{x m i t}^{m}
$$

Equations (6) and (7) are simply definitions, but $V^{*}$, as well as the $\delta$ s and $\varepsilon$ s, remain unobserved in both. 
To translate (6) and (7) into something we can estimate empirically, we first sum all industries for each year and pair of countries. Aggregate true (unobserved) trade between any two countries in year $t$ is just $V_{x m t}^{*}=\sum_{i=1}^{n} V_{x m i t}^{*}$; aggregate CIF costs are $\sigma_{x m t}=\sum_{i=1}^{n} \sigma_{x m i t}$; and aggregate random reporting errors are $\varepsilon_{x m t}^{x}=\sum_{i=1}^{n} \varepsilon_{x m i t}^{x}$ and $\varepsilon_{x m t}^{m}=\sum_{i=1}^{n} \varepsilon_{x m i t}^{m}$. Aggregate reported exports in (6) can be rewritten

$$
V_{x m t}^{x}=V_{x m t}^{*}\left(1+\bar{\delta}_{x m t}^{x}\right) \varepsilon_{x m t}^{x},
$$

where $V_{x m t}^{x}=\sum_{i=1}^{n} V_{x m i t}^{x}$ and

$$
\bar{\delta}_{x m t}^{x}=\sum_{i=1}^{n}\left(\frac{V_{x m i t}^{*} \varepsilon_{x m i t}^{x}}{V_{x m t}^{*} \varepsilon_{x m t}^{x}} \delta_{x m i t}^{x}\right)
$$

is the average degree of misreporting, weighted by the industry-level exports and reporting errors.

Similarly, aggregate reported imports in (7) become

$$
V_{x m t}^{m}=V_{x m t}^{*} \sigma_{x m t}\left(1+\bar{\delta}_{x m t}^{m}\right) \varepsilon_{x m t}^{m}
$$

where $V_{x m t}^{m}=\sum_{i=1}^{n} V_{x m i t}^{m}$ and

$$
\bar{\delta}_{x m t}^{m}=\sum_{i=1}^{n}\left(\frac{V_{x m i t}^{*} \sigma_{x m i t} \varepsilon_{x m i t}^{m}}{V_{x m t}^{*} \sigma_{x m t} \varepsilon_{x m t}^{m}} \delta_{x m i t}^{m}\right)
$$

is the average degree of misreporting, weighted by industry-level imports, reporting errors, and CIF costs.

Equations (8) and (10) are accounting identities showing that customs officials, and therefore researchers, observe only the reported aggregate values of FOB exports, $V_{x m t}^{x}$, and CIF imports, $V_{x m t}^{m}$, which are functions of three unobserved country characteristics: (i) the true value of goods traded, (ii) CIF trade costs, and (iii) a weighted average of exporters' and importers' intentional misreports. 
The final step is to take the ratio of aggregate reported imports in equation (10) to the aggregate reported exports in equation (8), yielding

$$
\frac{V_{x m t}^{m}}{V_{x m t}^{x}}=\frac{\sigma_{x m t}\left(1+\bar{\delta}_{x m t}^{m}\right) \varepsilon_{x m t}^{m}}{\left(1+\bar{\delta}_{x m t}^{x}\right) \varepsilon_{x m t}^{x}} .
$$

Taking the log of both sides of equation (12) we get

$$
\ln V_{x m t}^{m}-\ln V_{x m t}^{x}=\ln \sigma_{x m t}+\ln \left(1+\bar{\delta}_{x m t}^{m}\right)-\ln \left(1+\bar{\delta}_{x m t}^{x}\right)+\varepsilon_{x m t},
$$

where $\varepsilon_{x m t}=\ln \varepsilon_{x t}^{m}-\ln \varepsilon_{m t}^{x}$ is now a normally distributed error term for shipments from $x$ to $m$ in year $t$. We call the left-hand side of (13) the "log trade gap," and it forms the baseline for all of our empirical analyses.

In theory, even if we had data on $\sigma_{x m t}, \bar{\delta}_{x m t}^{m}$, and $\bar{\delta}_{x m t}^{x}$, we could not consistently estimate the log trade gap in (13) because those weighted average misreports $\left(\bar{\delta}_{x m t}^{m}\right.$ and $\bar{\delta}_{x m t}^{x}$ ) are themselves still functions of the unobserved true values of trade among industries (see equations (9) and (11)). To address the fact that we do not observe those $\bar{\delta}$ s, and that even if we could, they would be endogenous, we rely on a "proxy variable” estimation strategy to obtain consistent estimates of important characteristics that influence firms' decisions to misreport (Wooldridge 2010).

As a refresher, proxy variables can mitigate omitted variable bias like that in equation (13). Consider a variable $z$ to be used as a proxy for one of the missing $\delta$ s in (13). To be a sucessful proxy, $z$ must be redundant. That is,

$$
E\left(\ln V_{x m t}^{m}-\ln V_{x m t}^{x} \mid \delta, z\right)=E\left(\ln V_{x m t}^{m}-\ln V_{x m t}^{x} \mid \delta\right) .
$$

Or put differently, the expected trade gap estimated with and without the proxy $z$ is the same, once we've conditioned on the other right-hand variables $(\mathbf{X})$, including the missing one $(\delta)$. In what follows, we describe proxies for the missing $\delta$ s: country characteristics that change the costs or benefits to firms of misreporting their exports or imports. These include local taxes, tariffs, corruption, and accounting standards - the elements of $\mathbf{Z}^{m}$ and $\mathbf{Z}^{x}$ in equations (3) and (5).

The idea is similar to a standard instrumental variables approach, where instead of having an endogenous right-hand variable, we have an unobserved endogenous right-hand variable. Proxy variables, like instruments, must be correlated with the endogenous variable and 
uncorrelated with the dependent variable except mechanically through the endogenous righthand variable. And the empirical strategy is even simpler than for instruments. We simply substitute proxy variables for the $\bar{\delta}$ s in equation (13). That leaves us unable to estimate the direct effect of misreporting on the log trade gap but does allow us to consistently estimate the effect of the proxy variables on the log trade gap. As an auditing check on the extent of misreporting, that suffices. If there is no intentional misreporting, the $\bar{\delta}$ s are zero, and the coefficients on the proxies should be zero.

In our case, the proxies for the $\bar{\delta}$ s are just measures of the country characteristics, $\mathbf{Z}$, that determine firms’ optimal misreports in (3) and (5): taxes and tariffs, corruption and auditing standards, and trade agreements. The critical assumption is that these country characteristics, $\mathbf{Z}$, affect only the left-hand side of (13) through their effect on the $\bar{\delta}$ s. By taking the ratio of reported aggregate imports to exports, we have canceled out the true value of trade from our estimating equation, except where it appears in the weighted average of those misreports. But since we don’t observe the misreports anyway, only proxies for misreports, we can estimate equation (13) consistently using those proxies in lieu of the $\bar{\delta}$ s.

$$
\ln V_{x m t}^{m}-\ln V_{x m t}^{x}=\beta_{0}+\boldsymbol{\beta}_{1}^{\prime} \boldsymbol{\sigma}_{x m t}+\boldsymbol{\beta}_{2}^{\prime} \mathbf{Z}_{x m t}^{m}-\boldsymbol{\beta}_{3}^{\prime} \mathbf{Z}_{x m t}^{x}+\mu_{x m t}
$$

Equation (15) is essentially an auditing formula. If there is no misreporting, the

difference between the value of trade shipped from $x$ to $m$ should reflect only trade costs ( $\boldsymbol{\sigma})$ and a mean-zero random error $(\mu)$. That difference should not be a function of tariffs, accounting standards, taxes, or corruption. The coefficients in $\boldsymbol{\beta}_{2}$ and $\boldsymbol{\beta}_{3}$ should be zero.

Most importantly, we can estimate equation (15). We have data on components of trade costs, $\boldsymbol{\sigma}$, which are simply the standard elements of a gravity model of international trade such as distance, common borders, and language. And we have data on measures of country characteristics, $\mathbf{Z}$. We describe both in the section that follows.

\section{Data and Estimation}

Descriptive statistics for all the data we use are in Table 1. With 178 countries over 11 years, there are 346,566 possible annual trade flows in the Comtrade data used. ${ }^{16}$ But trade was reported in only about half of those. Unreported trade occurs either because countries do not

\footnotetext{
${ }^{16} 178 \times 177 \times 11$.
} 
trade with each other or because countries fail to report their trade. In no cases was there commerce reported by the exporter but not by the importer, or vice versa. In what follows, our analyses include the data only for years and country pairs with reported commerce. This reduces our potential available observation set to 165,215 . We also drop countries with missing audit, corruption, tariff, or ports data, and we drop cases with too few importers, exporters, or country pairs to identify country-pair fixed effects. Even without these observations, our final data set of 86,185 observations contains more than 87 percent of the reported imports for the 165,215 potential observations for which we have data during the time period. A detailed accounting of how we arrive at the 86,185 observations described in Table 1 can be found in Appendix Table A1. ${ }^{17}$

Our proxies for CIF trade costs are the standard components of a typical gravity model of international trade. ${ }^{18}$ These include distance between countries and whether they share common borders or languages. ${ }^{19}$ In addition, we include the quality of port infrastructure in the two countries, based on survey data from the Global Competitiveness Report (GCR) for the years 2002-2012. ${ }^{20}$ The survey question relating to port quality can be found in Appendix Table A2. Port quality is scaled from 1 to 7 , and we define a measure of port quality for each country pair by multiplying the importer and exporter scores. ${ }^{21}$

Weighted average tariff rates for each country and year were obtained from the World Bank Development Indicators (WBDI). ${ }^{22}$ Dummy variables for whether two countries are

\footnotetext{
${ }^{17}$ Trade data are available for many more years than we examine in this paper, but our analysis is constrained to 2002-2012 by the availability of proxy variable data on the strength of accounting and auditing standards and corruption.

${ }^{18}$ See Head and Mayer (2013) for a survey of the gravity model literature and variables used for approximating transport costs.

${ }^{19}$ Distance, common border, and common language are from the CEPII gravity database, which can be found at http://www.cepii.fr/CEPII/en/bdd_modele/presentation.asp?id=8.

${ }^{20}$ Country-level characteristics from survey questions from the GCR have been used extensively in empirical studies on international trade and investment. See Carr et al. (2001), Yeaple (2003), Javorcik and Wei (2004), Eckholm et al. (2007), and Kellenberg (2012) for a few of many examples.

${ }^{21}$ Better or more efficient port infrastructure decreases CIF costs (Clark et al. 2004).

${ }^{22}$ Simple unweighted average tariff rates are also available from the WBDI. However, the simple correlation between unweighted and weighted average tariff rates is 0.93 . All the regressions in the following discussion were also run with the unweighted average tariff rates, with virtually identical results. Thus, we present only the results using the weighted average tariff rates-theoretically a more accurate measure of countries' overall average tariff rates.
} 
members of an RTA, which may be a free trade area, customs union, or economic integration agreement, were generated using a data-generating program described in de Sousa (2012). ${ }^{23}$

Like port quality data, country data on average accounting and auditing standards come from the GCR surveys. The specific questions relating to the strength of auditing and accounting standards can be found in the second row of Appendix Table A2. This variable is also on a 1-to-7 scale, with higher scores indicating stronger standards. Corruption data come from Transparency International's Corruption Perceptions Index, ${ }^{24}$ which uses annual survey data to measure the perceived level of public corruption. The index ranges from 0 (very corrupt) to 10 (not corrupt).

Table 2 presents several estimates of equation (15). Column (1) estimates the simplest version of the basic model where we have included a single proxy variable for each of $\sigma_{x m t}$, $Z_{x m t}^{m}$, and $Z_{x m t}^{x},:$ port quality, tariffs, and exporter auditing and accounting standards. All three coefficients are statistically significant and negative, as expected. Higher tariffs increase the incentive to underreport imports, decreasing the gap between reported imports and exports. Better ports mean lower trade costs, shrinking the gap between true CIF imports and FOB exports. And exporting countries' auditing and accounting standards reduce the ability of firms to understate exports, shrinking the log trade gap.

In column (2) we add more proxies for trade costs: distance and indicators for common borders and common languages. All three proxies are statistically significant and of the expected signs. Distance increases trade costs, increasing the log trade gap, while common borders and language reduce trade costs with the opposite consequence. In columns (3) through (5) we add importer accounting standards an indicator for when both countries are members of an RTA as well as an interaction term between tariffs and RTAs. Better exporter accounting standards reduce the ability of firms to understate exports, shrinking the trade gap, while better importer accounting standards results in less underreporting of imports, increasing the trade gap. The effect of RTAs on the reported trade gap in columns (4) and (5) is negative. The estimates across all five specifications in columns (1) through (5) are remarkably stable, even as we add additional proxies to the model. This stability provides a degree of confidence in the reliability of our proxy variable estimation strategy.

\footnotetext{
${ }^{23}$ The Stata do-files for the RTA program can be found at http://jdesousa.univ.free.fr/data.htm. These files have been used in several prior studies on RTAs, such as Head et al. (2010), Baghdadi et al. (2013), and Head and Ries (2010).

${ }^{24}$ www.transparancy.org.
} 
In column (5) of Table 2 we add the interaction between tariffs and RTAs. The coefficient is positive and significant, indicating that the effect of tariff evasion on the reported trade gap is smaller for country pairs that are members of an RTA. At the bottom of column (5) we calculate the combined effects of tariffs for RTA members $(-1.69) .{ }^{25}$ A 1 percent increase in tariffs decreases the reported trade gap by 1.7 percent. Though statistically significant, this effect is much smaller than the -3.4 coefficient for country pairs that are not members of an RTA. That is, the tariff evasion effect is smaller between countries that are members of an RTA and presumably face lower average tariff rates than for country pairs that are not RTA members and face higher average tariff rates. Once we control for the different effects that RTAs have directly and through tariffs, the net effect of RTAs is both negative and statistically significant.

Even with a variety of proxies included in the estimation in columns (1) through (5), unobserved heterogeneity across time or specific country pairs could still bias the estimates. If there are unobserved country characteristics that influence reporting gaps and happen to be correlated with one of our proxies, then our estimates may be biased. For example, if stronger auditing and accounting standards across time happen to be correlated with unobserved technological advancements in computing and software capabilities in all countries, and this leads to a decrease in the random error component of misreporting, then our proxy estimates on auditing and accounting standards may be biased. Likewise, if some trading partners have cooperated to make sure that the data reported by exporters and importers match, that might shrink the reported trade gap. ${ }^{26}$ To the extent that this cooperation is correlated with other country characteristics, our estimates may be biased.

In column (6) of Table 2 we control for unobserved time-specific heterogeneity by including year dummies. Although some of the coefficient estimates change slightly from column (5), the results are quite similar, indicating that the effect of any bias from unobserved heterogeneity over time is minimal. In column (7) we add country-pair fixed effects. Two things are important to keep in mind here. First, all estimates are now identified from changes in variables within country pairs, as opposed to the cross-country pairs estimates in columns (1) through (6). Second, since we are controlling for time-invariant unobserved heterogeneity, we

\footnotetext{
${ }^{25}$ The combined effect of tariffs for RTA members is the sum of coefficients for [Importer Tariff ] + [Importer Tariff $\mathrm{x}$ RTA]. For column (5) of Table 2 this is $-3.40+1.71=-1.69$. An F-test was conducted to determine the joint significance of the sum.

${ }^{26}$ Since 1990 the United States and Canada have exchanged import data and substituted each other's reported import data for their own reported export data, which are typically less reliable (Stoyanov 2012).
} 
can no longer identify other time-invariant characteristics, such as distance or common borders and languages, since they are absorbed by the country-pair fixed effects. Only proxies that vary across time within country pairs can be identified. Moreover, some of the proxies that do vary over time don't vary by much, leaving little variance for identification. The coefficients on port quality, RTAs, and importer accounting standards are no longer statistically significant.

The coefficients in column (7) on tariffs and exporter accounting standards remain statistically significant, though their magnitudes change somewhat. The effect of tariffs for countries that are not members of the same RTA is -1.21 , but the effect for RTA members is not statistically different from zero (-0.18). The coefficient on exporters' auditing and accounting standards remains negative and significant: a one standard deviation increase in exporters auditing and accounting standards decreases the trade gap by 5.2 percent.

The regressions in columns (3) through (6) of Table 2 are repeated in columns (1) through (4) of Table 3, using the corruption index as a proxy for misreporting rather than auditing and accounting standards. The magnitudes and significance of the coefficients on tariffs, ports, distance, common language, common border, and RTAs remain nearly identical to the results in Table 2. Corruption also has statistically significant effects on the trade gap. A one standard deviation decrease in corruption (i.e., a higher corruption index score) in the exporting country translates to a 7.7 to 13 percent decrease in the trade gap, whereas a comparable decrease in corruption in the importing country implies approximately a 2.8 percent increase in the trade gap. This is consistent with the hypothesis that countries that have less corruption, or do a better job of controlling corruption, make it more difficult for exporters or importers to underreport true trade values.

In column (5) of Table 3 we estimate the model with both auditing and accounting standards and corruption as proxies for misreporting. The results are similar for all variables except that the signs on the coefficients for the importer and exporter auditing and accounting variables have reversed. This is a bit strange, but given the high simple correlation of the auditing and accounting standards variables and the corruption variables $(\rho=0.83)$, and the fact that the coefficients are identified across country pairs, we suspect a multicollinearity bias. In column (6) we again incorporate country-pair fixed effects. Here, the coefficients are now identified within country pairs over time, reducing the collinearity observed across country pairs in column (5). Both better auditing and accounting standards and less corruption in the exporting 
country now have the expected negative effect on the the trade gap; the results are positive but no longer statistically significant for importers. It is important to note that the country-pair fixed effects regressions in column (7) of Table 2 and columns (4) and (6) of Table 3 have far greater explanatory power than the regressions without country-pair fixed effects, indicating substantial unobserved country-pair heterogeneity in the trade gap. In the regressions that follow, we constrain our analysis to regressions that contain country-pair fixed effects.

In Table 4 we check the robustness of the results with respect to outlier observations. Recall from Figure 2 that the mean of the reported trade gap is clustered slightly above zero, but the gap increases again for values \pm 0.75 . To ensure that our results are not driven by the tails of the distribution, we repeat our most restrictive specification in column (7) of Table 3 using different cutoff values for the tails of the distribution: we drop observations where the trade gap is $\pm 0.99, \pm 0.75$, and \pm 0.5 . Although the magnitude of the coefficients on tariffs and exporter auditing and accounting standards and corruption falls as the sample size is further restricted, the coefficients remain economically and statistically significant, indicating that their effects are not being driven solely by extreme country-pair observations.

\section{WTO Membership, Product Taxes, and Capital Controls}

In Table 5 we explore additional versions of equation (15). Column (1) adds a dummy for World Trade Organization (WTO) membership as well as an interaction with tariff rates to see whether WTO membership has had similar effects on the trade gap as RTA membership. ${ }^{27}$ Although WTO membership does not reduce average tariff rates to the extent a free trade agreement or customs union might, most-favored-nation status may lower average tariff rates for members and provide benefits similar to RTA membership. However, 90 percent of the annual trade flows in our data were between pairs of contries that were WTO members over the entire sample period, making any WTO effect difficult to identify. This may explain the insignificance of both the direct WTO coefficient and the WTO effect through tariffs. Nonetheless, the insignificant net effect of WTO membership on the overall trade gap is consistent with Javorcik and Narciso (2013), who also found that WTO membership has led to no net difference in the reported trade gap for 15 recent member countries. Importantly, parameter estimates on tariffs,

\footnotetext{
${ }^{27}$ Data on World Trade Organization membership were obtained from accession dates on the WTO website, at https://www.wto.org/.
} 
auditing and accounting standards, and corruption in the exporting country remain consistent and significant.

In columns (2) and (3) of Table 5 we examine product tax rates. Higher product taxes in the exporting country give firms the incentive to understate exports, increasing the reported gap measured as $V_{x m}^{m}-V_{x m}^{x}$. But higher product taxes in the importing country lead to understated imports, shrinking the reported trade gap. We calculate net product tax rates as the tax revenues (minus subsidies) that are related to the sale, production, or use of goods and services in a country, divided by GDP. This measure provides a proxy of the net tax rates on goods and services faced by importers and exporters across countries. ${ }^{28}$ Data coverage on tax rates, however, is not as extensive as for the other variables in Table 5, with only 64,429 observations available. Moreover, most of the lost observations come from less developed countries with less reliable tax data. Given that we are not only adding tax rates as additional proxies but also substantially altering our sample, in column (2) we first run the same regression as in column (7) of Table 3 to understand how changing the sample size affects the results. Then in column (3) we add net taxes on products for both exporters and importers.

Despite the decrease in observations, the results in column (2) are remarkably similar to those using the full sample. In column (3) of Table 5 the coefficient on exporter net product taxes (1.34) is large, of the expected sign, and statistically significant. A 1 percent increase in exporting country tax rates increases exporters’ underreporting and leads to a 1.34 percent increase in the reported trade gap.

Finally, in columns (4) through (5) of Table 5 we include proxies for capital controls. In theory, capital export controls give firms incentives to understate exports, increasing the trade gap $\left(V_{x m}^{m}-V_{x m}^{x}\right)$, whereas capital import controls give firms the incentive to understate imports, decreasing the trade gap. Although we don't have data on the strength of capital controls, one potential proxy is inflation rates. Inflation can be correlated with large capital inflows that make it difficult for countries to control monetary policy without capital control restrictions (Cordero

\footnotetext{
${ }^{28}$ Data on both net taxes on products and GDP are from the WBDI database. We also explored but do not present here other tax rate proxies found in the WBDI, including measures of value added tax revenues and overall tax revenues as a percentage of GDP. However, these other measures were always insignificant, did not qualitatively change the results of any of the other relevant variables in the model, and suffered from more severe missing data problems.
} 
and Montecino 2010; Lartey 2012). And Lemmen and Eijffinger (1996) find a positive correlation between inflation rates and measures of capital controls.

Again, incomplete inflation data across countries reduce our available sample size to $83,735 .{ }^{29}$ To ensure that any changes in coefficient estimates are not the result of the changing sample, in column (4) of Table 5 we again estimate the base model of column (7) in Table 2 on the new smaller sample. The effects of tariffs and exporter accounting standards and corruption remain stable and statistically significant. In column (5) the signs on exporter and importer inflation rates are of opposing signs, consistent with firms' having incentives to use trade misreporting to move capital. These effects are not statistically significant, however. Importantly, the estimates on tariff rates and exporter accounting standards and corruption continue to remain consistently significant and robust to changing samples and the inclusion of alternative proxies.

\section{Different Effects for Rich and Poor Countries}

As an additional check on our results, we explore whether tariffs, auditing and accounting standards, and corruption have different effects on countries of different development levels. Defining high-income countries using the World Bank's classification, we interact an indicator for these countries with our tariff, auditing and accounting, and corruption measures. The interaction terms tell us how the marginal effects of high-income countries differ from the marginal effects of lower-income countries, which we define as all countries not classified as high income. The results of the interactions are presented in Table 6, where column (1) includes interactions with tariffs, column (2) has interactions with accounting standards, and column (3) has interactions with corruption. In general, there appears to be no difference in the effects of auditing and accounting standards for high- and lower-income countries. There are, however, intriguing differences in tariff evasion and importer corruption effects.

To facilitate discussion of these differences, Table 7 reports the combined marginal effects of high- and lower-income countries from the regression results in Table 6. For both country categories, tariffs have a negative and statistically significant effect on the reported trade gap when a country imports from a non-RTA trading partner, but the effect in high-income countries is three times larger than the effect in lower-income countries. This difference is both

\footnotetext{
${ }^{29}$ Inflation rate data also come from the WBDI database.
} 
statistically and economically significant. However, when trading partners are members of the same RTA, for lower-income importers the tariff effect is not statistically different from zero, but for high-income importers it remains significant. The results indicate that tariff evasion is more prevelant in high-income importing countries both within and outside RTAs. We cannot say why there is such a discrepancy in the trade gap between high- and lower-income importing countries with respect to the tariff elasticity. However, given that high-income countries have more multinational firms ${ }^{30}$ and consume a greater proportion of differentiated products with larger markups, ${ }^{31}$ and given that those markups create more opportunity for transfer pricing within firms, ${ }^{32}$ we speculate that multinational firm transfer pricing in high-income importing countries may play a role in the larger trade elasticity gap. However, testing this is outside the scope of this paper, given multicountry panel data limitations for multinational enterprises.

The marginal effect of stronger auditing and accounting standards is statistically significant in both high- and lower-income countries, with the effect in lower-income countries slightly stronger. The difference between the two, however, is not statistically significant. Finally, the marginal effects of corruption in the exporting countries is similar and statistically significant for both high- and lower-income countries. Additionally, corruption has a positive and significant ${ }^{33}$ sign for lower-income importing countries, as would be expected (recall that the corruption index score is higher for less perceived corruption). Less corruption is likely correlated with less underrreporting of imports, which would increase the reported trade gap. In this case, a one standard deviation increase in the corruption index in a low-income importing country leads to a 3.7 percentage increase in the reported trade gap. ${ }^{34}$ Our results suggest that although improvements in auditing and accounting standards across countries can substantially reduce the extent of misreported trade, the elimination of corruption can have even larger effects, particularly for lower-income countries.

\section{Conclusion}

This paper finds evidence of intentionally misreported trade by examining the difference between trade reported by exporters and importers. Our approach differs in several ways from

\footnotetext{
${ }^{30}$ Markusen (2002).

${ }^{31}$ Markusen (2013).

${ }^{32}$ Clausing (2003).

33 Significant at the 10 percent level.

34 The standard deviation in the log of the corruption perception index for lower-income countries is 0.31 .
} 
prior studies. First, by using a panel of data on aggregate trade among hundreds of countries over 11 years, rather than detailed industry data for specific pairs of countries or regions, we can test for general patterns of tariff evasion. In this sense, our results apply to a broad range of countries at different levels of development and across all sectors of the economy. Second, we can break down those general results and compare tariff evasion in rich and poor countries as well as among trade agreement members and nonmembers. And third, we can examine country characteristics aside from tariffs that cause firms to misreport trade, including taxes, auditing standards, corruption, and capital controls.

For countries that are not members of regional trade agreements, higher tariffs are associated with significant underreporting of imports. And for high-income non-RTA members, the tariff evasion elasticity is three times larger than for low-income non-RTA members. For country pairs that are members of the same RTA, the tariff evasion effect disappears, although not completely for high-income importing countries. Tariff evasion is simply not a relevant motivation for misreporting when average tariff rates are near zero for most countries. The results indicate that tariff evasion effects are dependent on both the level of development across countries as well as their participation in RTAs.

In addition, we find robust evidence that underreporting of exports increases when auditing and accounting standards are lower and exporters' tax rates are higher. Likewise, eliminating corruption decreases misreporting for both importers and exporters, particularly in low-income countries.

These last results confirm that when we look beyond disaggregated tariff rates, policyrelevant country characteristics such as domestic tax rates, the strength of auditing and accounting standards, and corruption are significant in explaining firms’ motivations for underreporting of exports. These factors must be taken into account by governments and customs authorities seeking to protect revenue sources associated with tariff and tax evasion on trade across international borders. 


\section{References}

Baghdadi, Leila, Immaculada Martinez-Zarzoso, Celestino Suarez-Burguet, and Habib Zitouna. 2013. Are RTA agreements with environmental provisions reducing emissions? Journal of International Economics 90(2): 378-90.

Bouët, Antoine, and Devesh Roy. 2012. Trade protection and tax evasion: Evidence from Kenya, Mauritius, and Nigeria. Journal of International Trade \& Economic Development: An International and Comparative Review 21(2): 287-320.

Carr, David L., James R. Markusen, and Keith E. Maskus. 2001. Estimating the knowledgecapital model of the multinational enterprise. American Economic Review 91(3): 9951001.

Carrére, Celine. 2006. Revisiting the effects of regional trade agreements on trade flows with proper specification of the gravity model. European Economic Review 50(2): 223-47.

Clark, Ximena, David Dollar, and Alejandro Micco. 2004. Port efficiency, maritime transport costs, and bilateral trade. Journal of Development Economics 75(2): 417-50.

Clausing, Kimberly A. 2003. Tax-motivated transfer pricing and US intrafirm trade prices. Journal of Public Economics 87(9): 2207-23.

Collier, Paul, and Anthony J. Venables. 2011. Illusory revenue: Import tariffs in resource-rich and aid-rich economies. Journal of Development Economics 94: 202-206.

Cordero, José Antonio, and Juan Antonio Montecino. 2010. Capital controls and monetary policy in developing countries. CEPR working paper.

de Sousa, Jose. 2012. The currency union effect on trade is decreasing over time. Economics Letters 117(3): 917-20.

Dutt, Pushan, and Daniel Traca. 2010. Corruption and bilateral trade flows: Extortion or evasion. Review of Economics and Statistics 92(4): 843-60.

Ekholm, Karolina, Rikard Forslid, and James R. Markusen. 2007. Export platform foreign direct investment. Journal of the European Economic Association 5(4): 776-95.

Epaphra, Manamba. 2015. Tax rates and tax evasion: Evidence from missing imports in Tanzania. International Journal of Economics and Finance. 7(2): 122-37.

Ferrantino, Michael J., Xuepeng Liu, and Zhi Wang. 2012. Evasion behaviors of exporters and importers: Evidence from the U.S.-China trade data discrepancy. Journal of International Economics 86: 141-57. 
Fisman, Raymond, and Shang-Jin Wei. 2004. Tax rates and tax evasion: Evidence from "missing imports” in China. Journal of Political Economy 112(2): 471-96.

Head, Keith, and Thierry Mayer. 2013. Gravity equations: Workhorse, toolkit, and cookbook. CEPII working paper 2013-27.

Head, Keith, and John Ries. 2010. Do trade missions increase trade? Canadian Journal of Economics 43(3): 754-75.

Head, Keith, Thierry Mayer, and John Ries. 2010. The erosion of colonial trade linkages after independence. Journal of International Economics 81(1): 1-14.

Javorcik, Beata S., and Gaia Narciso. 2013. Accession to the World Trade Organization and tariff evasion. CEPR discussion paper 9592.

Javorcik, Beata S., and Shang-Jin Wei. 2004. Pollution havens and foreign direct investment: Dirty secret or popular myth? Contributions to Economic Analysis \& Policy 3(2): Article 8.

Kar, Dev, and Joseph Spanjers. 2014. Illicit financial flows from developing countries: 20032012. Global Financial Integrity report. Available at http://www.gfintegrity.org/report/2014-global-report-illicit-financial-flows-fromdeveloping-countries-2003-2012/.

Kellenberg. 2012. Trading Wastes. Journal of Environmental Economics and Management 64(1): 68-87.

Kim, Sunghyun H., and M. Ayhan Kose. 2014. Welfare implications of trade liberalization and fiscal reform: A quantitative experiment. Journal of International Economics 92: 198209.

Lartey, Emmanuel K.K. 2012. Financial openness, nontradable inflation and optimal monetary policy. Economics Letters 117: 782-85.

Lemmen, Jan J.G., and Sylvester C.W. Eijffinger. 1996. The fundamental determinants of financial integration in the European Union. Weltwirtschaftliches Archiv 123(3): 432-56.

Magee, Chris. 2008. New measures of trade creation and trade diversion. Journal of International Economics 75: 340-62.

Markusen, James R. 2002. Multinational firms and the theory of international trade. Cambridge, MA: MIT Press.

- 2013. Putting per-capita income back into trade theory. Journal of International Economics 90(2): 255-65. 
Mishra, Prachi, Arvind Subramanian, and Petia Topalova. 2008. Tariffs, enforcement, and customs evasion: Evidence from India. Journal of Public Economics 92: 1907-25.

Patnaik, Ila, Abhijit Sen Gupta, and Ajay Shah. 2012. Determinants of trade misinvoicing. Open Economies Review 23: 891-910.

Prasad, Eswar S., and Raghuram G. Rajan. 2008. A pragmatic approach to capital account liberalization. Journal of Economic Perspectives 22(3): 149-72.

Stoyanov, Andrey. 2012. Tariff evasion and rules of origin violations under the Canada-U.S. Free Trade Agreement. Canadian Journal of Economics 45(3): 879-902.

Wooldridge, Jeffrey. 2010. Econometric analysis of cross section and panel data. Cambridge, MA: MIT Press.

Yeaple, Stephen R. 2003. The role of skill endowments in the structure of U.S. outward foreign direct investment. Review of Economics and Statistics 85(3): 726-34. 
Figure 1: Total Global Trade as Reported by Importers and Exporters

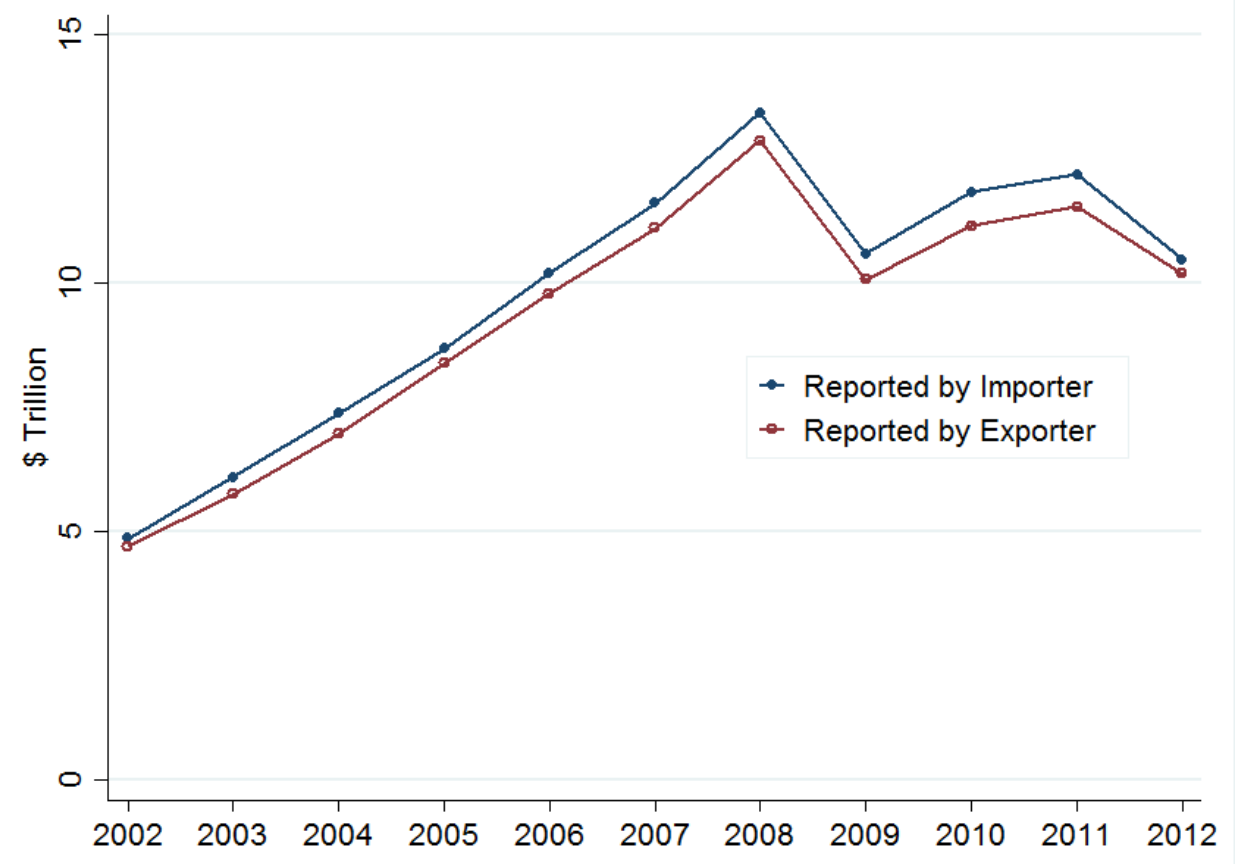

Figure 2: Trade Reporting Gap by Country-Pair Year

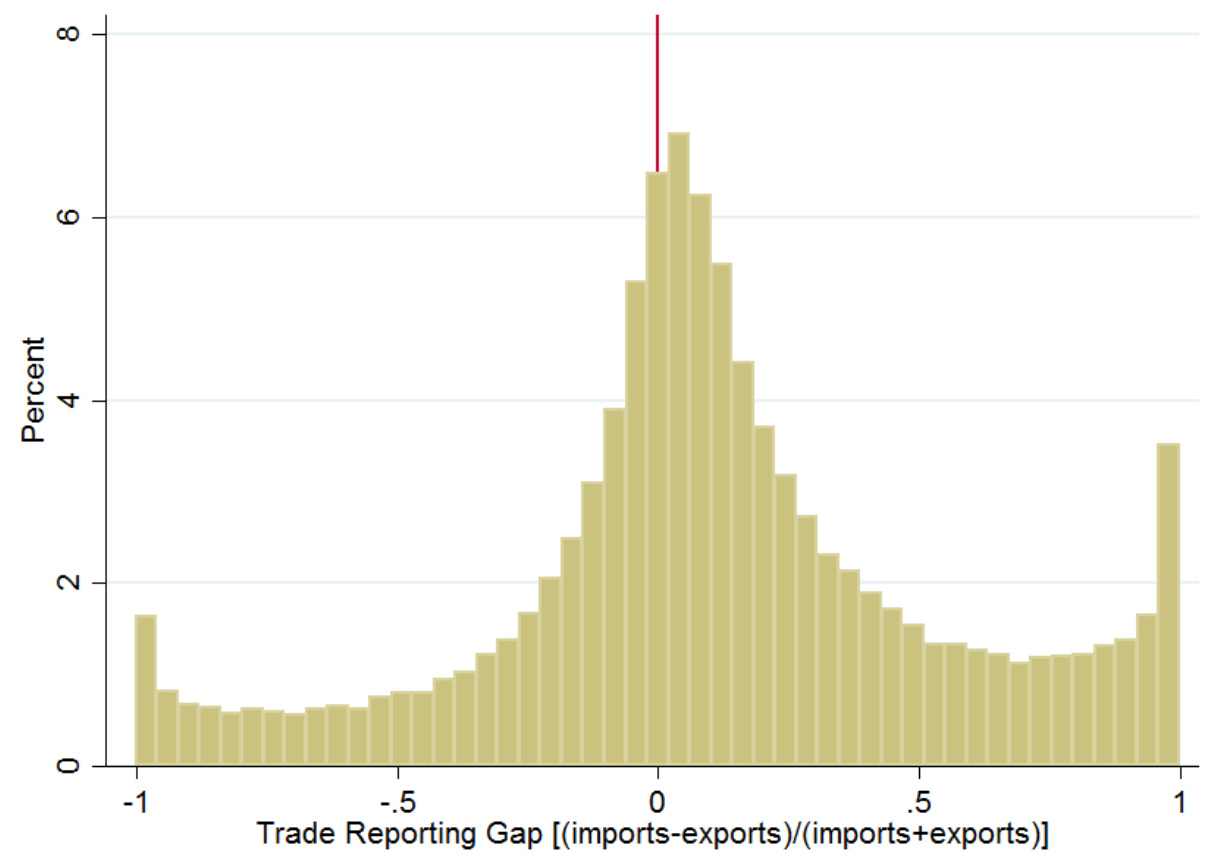


Figure 3: Trade Reporting Gap by Tariff

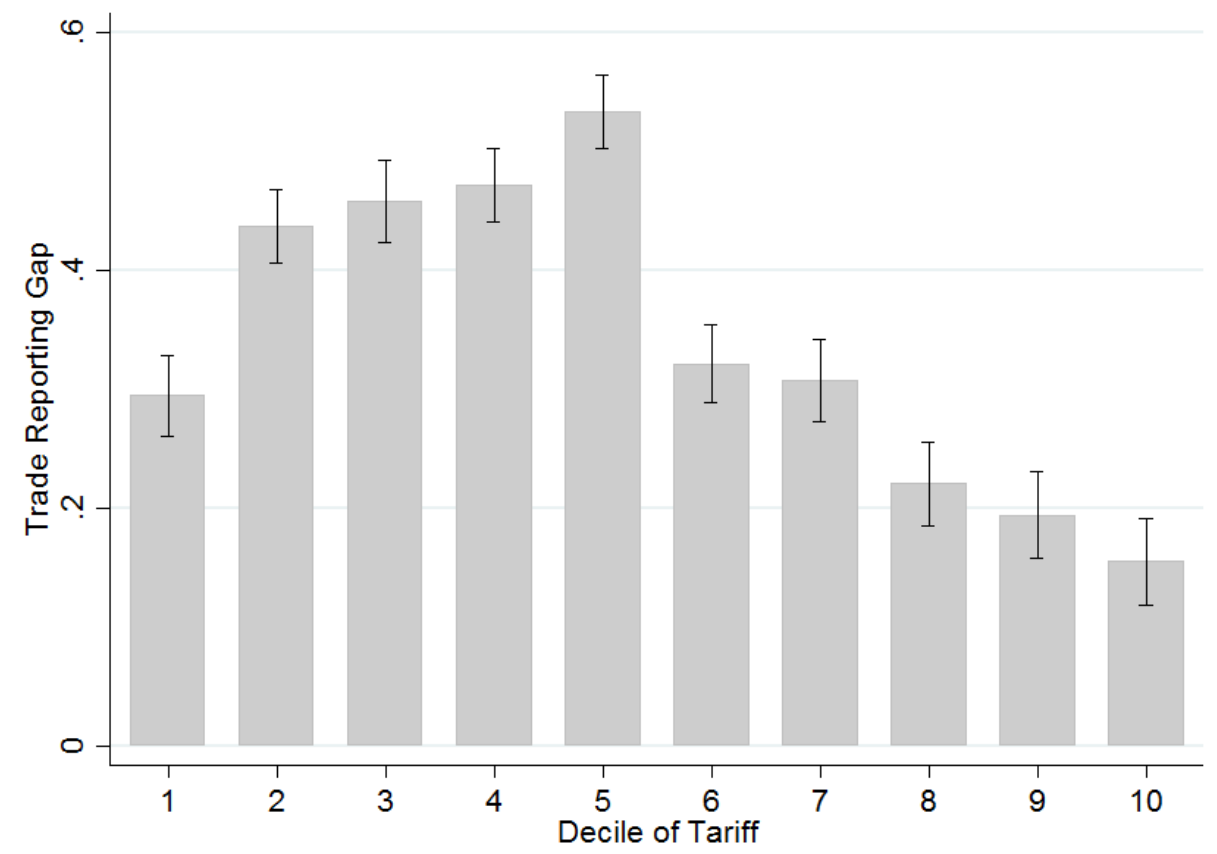

Figure 4: Trade Reporting Gap by Exporter Characteristics

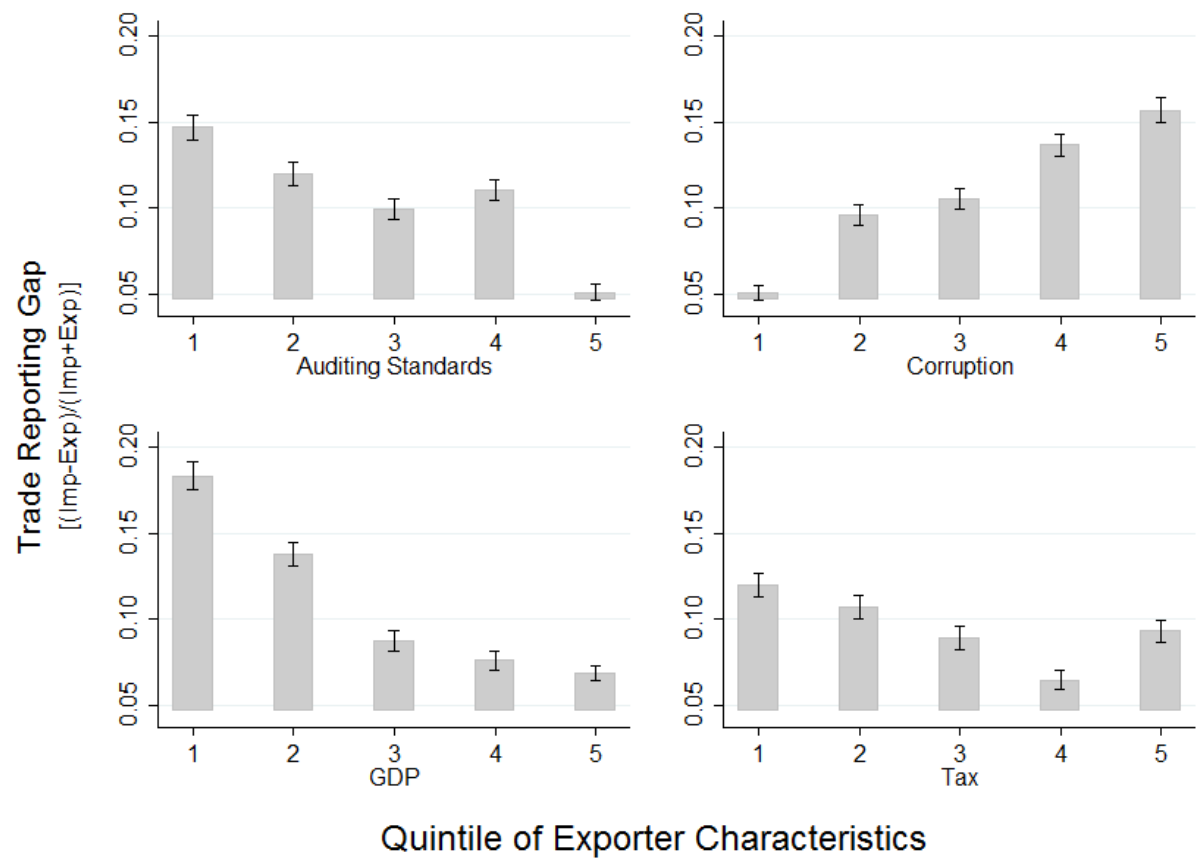


Figure 5: Trade Reporting Gap by Importer Characteristics

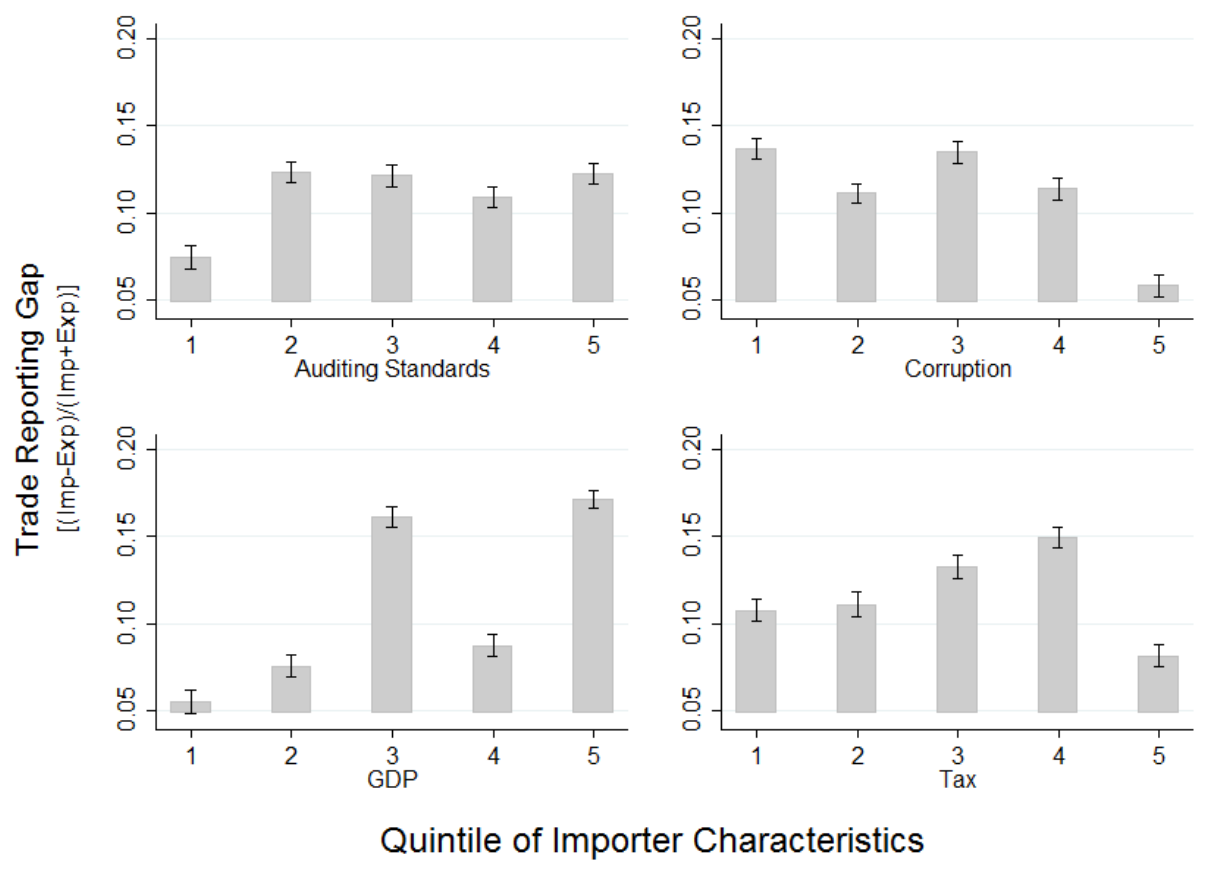


Table 1: Descriptive Statistics

\begin{tabular}{lccccc} 
& & & Std. & \\
Variable & Obs & Mean & Dev. & Min & Max \\
\hline Evasion Gap [Ln(Imports)-Ln(Exports)] & 86,185 & 0.31 & 1.57 & -14.5 & 16.5 \\
Regional Trade Agreement & 86,185 & 0.23 & 0.42 & 0 & 1 \\
Both Countries WTO Members & 86,185 & 0.89 & 0.31 & 0 & 1 \\
Ln[Exporter Auditing and Accounting Standards] & 86,185 & 1.57 & 0.18 & 0.95 & 1.89 \\
Ln[Importer Auditing and Accounting Standards] & 86,185 & 1.57 & 0.19 & 0.95 & 1.89 \\
Ln[Bilateral Port Quality] & 86,185 & 2.80 & 0.45 & 0.50 & 3.82 \\
Share a Common Border & 86,185 & 0.03 & 0.17 & 0 & 1 \\
Ln[Bilateral distance between countries] & 86,185 & 8.56 & 0.91 & 4.08 & 9.89 \\
Common Offical Language & 86,185 & 0.12 & 0.33 & 0 & 1 \\
Ln[Exporter Corruption Perceptions Index] & 86,185 & 1.46 & 0.47 & 0.18 & 2.27 \\
Ln[Importer Corruption Perceptions Index] & 86,185 & 1.50 & 0.47 & 0.18 & 2.27 \\
Importer Tariff Rate (weighted average) & 86,185 & 0.04 & 0.04 & 0 & 0.26 \\
Exporter Net Taxes on Products (\% of GDP) & 64,429 & 0.10 & 0.04 & 0.002 & 0.24 \\
Importer Net Taxes on Products (\% of GDP) & 64,429 & 0.10 & 0.03 & 0.002 & 0.24 \\
Exporter Inflation Rate, GDP deflator (\%) & 83,735 & 0.06 & 0.08 & -0.33 & 1.04 \\
Importer Inflation Rate, GDP deflator (\%) & 83,735 & 0.06 & 0.07 & -0.25 & 1.04 \\
\hline Note: See Appendix Table A1 for how we get from 346,566 & possible annual country pairs to \\
the 86,185 described above and used in our analysis. & & & &
\end{tabular}


Table 2: Baseline Regressions on the Reported Trade Gap

\begin{tabular}{|c|c|c|c|c|c|c|c|}
\hline Dep. var: $\ln V^{m}-\ln V^{x}$ & (1) & (2) & (3) & (4) & (5) & (6) & (7) \\
\hline \multirow[t]{2}{*}{ Importer Tariff } & $-2.81 *$ & $-3.21^{*}$ & $-3.12^{*}$ & $-3.14 *$ & $-3.40 *$ & $-3.35 *$ & $-1.22 *$ \\
\hline & $(0.15)$ & $(0.16)$ & $(0.16)$ & $(0.16)$ & $(0.18)$ & $(0.18)$ & $(0.35)$ \\
\hline \multirow[t]{2}{*}{ Importer Tariff $\times$ RTA } & & & & & $1.71 *$ & $1.73^{*}$ & $1.03^{*}$ \\
\hline & & & & & $(0.30)$ & $(0.30)$ & $(0.48)$ \\
\hline \multirow[t]{2}{*}{ Ln[Port Quality] } & $-0.186^{*}$ & $-0.190 *$ & $-0.206^{*}$ & $-0.204^{*}$ & $-0.205^{*}$ & $-0.224^{*}$ & -0.036 \\
\hline & $(0.015)$ & $(0.015)$ & $(0.018)$ & $(0.018)$ & $(0.018)$ & (0.019) & $(0.039)$ \\
\hline \multirow[t]{2}{*}{ Ln[Distance $]$} & & $0.157^{*}$ & $0.157^{*}$ & $0.149 *$ & $0.147^{*}$ & $0.147^{*}$ & \\
\hline & & $(0.005)$ & $(0.005)$ & $(0.007)$ & $(0.007)$ & $(0.007)$ & \\
\hline \multirow[t]{2}{*}{ Common Border } & & $-0.171^{*}$ & $-0.169 *$ & $-0.170 *$ & $-0.181^{*}$ & $-0.181^{*}$ & \\
\hline & & $(0.023)$ & $(0.023)$ & $(0.023)$ & $(0.023)$ & $(0.023)$ & \\
\hline \multirow[t]{2}{*}{ Common Offical Language } & & $-0.151^{*}$ & $-0.154 *$ & $-0.154^{*}$ & $-0.161^{*}$ & $-0.162^{*}$ & \\
\hline & & $(0.016)$ & $(0.016)$ & $(0.016)$ & $(0.016)$ & $(0.016)$ & \\
\hline \multirow[t]{2}{*}{ Ln[Exporter Auditing Stds] } & $-0.271 *$ & $-0.246^{*}$ & $-0.225^{*}$ & $-0.217^{*}$ & $-0.207^{*}$ & $-0.185^{*}$ & $-0.290^{*}$ \\
\hline & $(0.036)$ & $(0.036)$ & $(0.038)$ & $(0.038)$ & $(0.038)$ & $(0.039)$ & $(0.089)$ \\
\hline \multirow[t]{2}{*}{ Ln[Importer Auditing Stds] } & & & 0.070 & 0.075 & 0.075 & $0.102 *$ & 0.086 \\
\hline & & & $(0.039)$ & $(0.039)$ & $(0.039)$ & $(0.041)$ & $(0.092)$ \\
\hline \multirow[t]{2}{*}{ Regional Trade Agreement } & & & & -0.026 & $-0.084^{*}$ & $-0.085^{*}$ & -0.062 \\
\hline & & & & $(0.015)$ & $(0.019)$ & $(0.019)$ & $(0.048)$ \\
\hline Year Dummies & No & No & No & No & No & Yes & Yes \\
\hline Bilateral Dummies & No & No & No & No & No & No & Yes \\
\hline \multirow[t]{2}{*}{ Constant } & $1.38^{*}$ & 0.050 & -0.051 & -0.004 & 0.020 & -0.005 & \\
\hline & $(0.05)$ & $(0.070)$ & $(0.086)$ & $(0.092)$ & $(0.093)$ & $(0.095)$ & \\
\hline \multicolumn{8}{|l|}{ Effect of Tariffs among RTA } \\
\hline Members & & & & & $-1.69 *$ & $-1.62 *$ & -0.18 \\
\hline F-stat & & & & & 44.0 & 39.3 & 0.16 \\
\hline Observations & 86,185 & 86,185 & 86,185 & 86,185 & 86,185 & 86,185 & 86,185 \\
\hline R-squared & 0.01 & 0.02 & 0.02 & 0.02 & 0.02 & 0.02 & 0.57 \\
\hline
\end{tabular}


Table 3: The Effects of Corruption on the Reported Trade Gap

\begin{tabular}{|c|c|c|c|c|c|c|}
\hline Dep. var: $\ln V^{m}-\ln V^{x}$ & (1) & (2) & (3) & (4) & (5) & (6) \\
\hline \multirow[t]{2}{*}{ Importer Tariff } & $-2.716^{*}$ & $-2.940^{*}$ & $-2.871^{*}$ & $-1.166^{*}$ & $-2.846^{*}$ & $-1.174^{*}$ \\
\hline & $(0.170)$ & (0.189) & (0.195) & $(0.351)$ & $(0.195)$ & $(0.351)$ \\
\hline \multirow[t]{2}{*}{ Importer Tariff $\times$ RTA } & & $1.426^{*}$ & $1.453^{*}$ & $1.070^{*}$ & $1.465^{*}$ & $1.071^{*}$ \\
\hline & & $(0.301)$ & $(0.301)$ & $(0.483)$ & $(0.300)$ & $(0.483)$ \\
\hline \multirow[t]{2}{*}{ Ln[Port Quality] } & $-0.163^{*}$ & $-0.164^{*}$ & $-0.181^{*}$ & -0.0334 & $-0.191 *$ & -0.027 \\
\hline & $(0.019)$ & (0.019) & $(0.020)$ & $(0.038)$ & $(0.021)$ & $(0.039)$ \\
\hline \multirow[t]{2}{*}{ Ln[Distance] } & $0.147^{*}$ & $0.145^{*}$ & $0.146^{*}$ & & $0.143 *$ & \\
\hline & $(0.007)$ & $(0.007)$ & $(0.007)$ & & $(0.007)$ & \\
\hline \multirow[t]{2}{*}{ Common Border } & $-0.176^{*}$ & $-0.185^{*}$ & $-0.185^{*}$ & & $-0.185^{*}$ & \\
\hline & $(0.023)$ & $(0.023)$ & $(0.023)$ & & $(0.023)$ & \\
\hline \multirow[t]{2}{*}{ Common Offical Language } & $-0.165^{*}$ & $-0.171^{*}$ & $-0.171^{*}$ & & $-0.174 *$ & \\
\hline & $(0.016)$ & $(0.016)$ & $(0.016)$ & & $(0.016)$ & \\
\hline \multirow[t]{2}{*}{ Ln[Exporter Auditing Stds] } & & & & & $0.283^{*}$ & $-0.204^{*}$ \\
\hline & & & & & $(0.058)$ & $(0.094)$ \\
\hline \multirow[t]{2}{*}{ Ln[Importer Auditing Stds] } & & & & & $-0.167^{*}$ & 0.061 \\
\hline & & & & & $(0.056)$ & $(0.096)$ \\
\hline \multirow[t]{2}{*}{ Ln[Exporter Corruption] } & $-0.176^{*}$ & $-0.172 *$ & $-0.164 *$ & $-0.286^{*}$ & $-0.248^{*}$ & $-0.252 *$ \\
\hline & $(0.015)$ & $(0.015)$ & $(0.015)$ & $(0.071)$ & $(0.022)$ & $(0.074)$ \\
\hline \multirow[t]{2}{*}{ Ln[Importer Corruption] } & $0.051^{*}$ & $0.051^{*}$ & $0.061 *$ & 0.061 & $0.123 *$ & 0.046 \\
\hline & $(0.017)$ & $(0.017)$ & $(0.018)$ & $(0.063)$ & $(0.024)$ & $(0.065)$ \\
\hline \multirow[t]{2}{*}{ Regional Trade Agreement } & -0.009 & $-0.058 *$ & $-0.059 *$ & -0.065 & $-0.062^{*}$ & -0.063 \\
\hline & $(0.015)$ & $(0.019)$ & $(0.019)$ & $(0.048)$ & (0.019) & $(0.048)$ \\
\hline Year Dummies & No & No & Yes & Yes & Yes & Yes \\
\hline Bilateral Dummies & No & No & No & Yes & No & Yes \\
\hline \multirow[t]{2}{*}{ Constant } & $1.382 *$ & 0.050 & & & & \\
\hline & $(0.053)$ & $(0.070)$ & & & & \\
\hline $\begin{array}{l}\text { Effect of Tariffs among RTA } \\
\text { Members }\end{array}$ & & $-1.514^{*}$ & $-1.418^{*}$ & -0.096 & $-1.381^{*}$ & -0.103 \\
\hline F-stat & & 33.2 & 28.1 & 0.04 & 26.82 & 0.05 \\
\hline Observations & 86,185 & 86,185 & 86,185 & 86,185 & 86,185 & 86,185 \\
\hline R-squared & 0.02 & 0.02 & 0.02 & 0.57 & 0.02 & 0.57 \\
\hline
\end{tabular}

* $p<0.05$. Robust standard errors in columns (1)-(3) and (5) in parentheses. In columns (4) and (6), robust standard errors are clustered on bilateral country pairs. 
Table 4: Robustness Regressions on Outlier Observations on the Reported Trade Gap

Drop observations where absolute value of trade gap percentage is greater than ...

\begin{tabular}{|c|c|c|c|}
\hline & 0.99 & 0.75 & 0.5 \\
\hline Dep. var: $\ln V^{m}-\ln V^{x}$ & $(1)$ & (2) & (3) \\
\hline \multirow[t]{2}{*}{ Importer Tariff } & $-1.076^{*}$ & $-0.718 *$ & $-0.622 *$ \\
\hline & $(0.282)$ & $(0.167)$ & $(0.117)$ \\
\hline \multirow[t]{2}{*}{ Importer Tariff $\times$ RTA } & $1.041^{*}$ & 0.280 & 0.188 \\
\hline & $(0.416)$ & $(0.270)$ & (0.199) \\
\hline \multirow[t]{2}{*}{ Ln[Port Quality] } & -0.015 & 0.006 & 0.004 \\
\hline & $(0.031)$ & $(0.018)$ & $(0.013)$ \\
\hline \multirow{2}{*}{ Ln[Exporter Auditing Stds] } & $-0.263^{*}$ & $-0.122 *$ & $-0.100 *$ \\
\hline & $(0.075)$ & $(0.045)$ & $(0.031)$ \\
\hline \multirow[t]{2}{*}{ Ln[Importer Auditing Stds] } & 0.090 & 0.056 & 0.038 \\
\hline & $(0.075)$ & $(0.044)$ & $(0.031)$ \\
\hline \multirow[t]{2}{*}{ Ln[Exporter Corruption] } & -0.100 & $-0.073^{*}$ & $-0.052^{*}$ \\
\hline & $(0.057)$ & $(0.034)$ & $(0.024)$ \\
\hline \multirow[t]{2}{*}{ Ln[Importer Corruption] } & 0.052 & 0.015 & -0.001 \\
\hline & $(0.053)$ & $(0.032)$ & $(0.023)$ \\
\hline \multirow[t]{2}{*}{ Regional Trade Agreement } & $-0.077^{*}$ & $-0.057^{*}$ & $-0.033^{*}$ \\
\hline & $(0.035)$ & $(0.022)$ & $(0.016)$ \\
\hline Year Dummies & Yes & Yes & Yes \\
\hline Bilateral Dummies & Yes & Yes & Yes \\
\hline Effect of Tariffs among RTA Members & -0.035 & -0.438 & $-0.434^{*}$ \\
\hline F-stat & 0.01 & 3.02 & 5.2 \\
\hline Observations & 84,365 & 73,745 & 63,862 \\
\hline R-squared & 0.56 & 0.54 & 0.54 \\
\hline
\end{tabular}

$* p<0.05$. Robust standard errors in columns (1)-(5) in parentheses. In column (6), robust standard errors are clustered on bilateral country pairs. 
Table 5: Robustness Regressions on WTO, Tax Rates, and Capital Controls

\begin{tabular}{|c|c|c|c|c|c|}
\hline Dep. var: $\ln \mathrm{V}^{\mathrm{m}}-\ln \mathrm{V}^{\mathrm{x}}$ & (1) & (2) & (3) & (4) & (5) \\
\hline \multirow[t]{2}{*}{ Importer Tariff } & $-1.446^{*}$ & $-1.100 *$ & $-1.102^{*}$ & $-0.973^{*}$ & $-0.985^{*}$ \\
\hline & $(0.711)$ & $(0.400)$ & $(0.405)$ & $(0.355)$ & $(0.355)$ \\
\hline \multirow[t]{2}{*}{ Importer Tariff $\times$ RTA } & $1.015^{*}$ & $1.167^{*}$ & $1.157^{*}$ & 0.834 & 0.876 \\
\hline & $(0.484)$ & $(0.513)$ & $(0.512)$ & $(0.486)$ & $(0.486)$ \\
\hline \multirow[t]{2}{*}{ Importer Tariff $\times$ WTO } & 0.0689 & & & & \\
\hline & $(0.052)$ & & & & \\
\hline \multirow[t]{2}{*}{ Ln[Port Quality] } & -0.025 & -0.032 & -0.035 & -0.056 & -0.054 \\
\hline & (0.039) & $(0.044)$ & $(0.044)$ & $(0.040)$ & $(0.040)$ \\
\hline \multirow[t]{2}{*}{ Ln[Exporter Auditing Stds] } & $-0.207^{*}$ & -0.189 & -0.204 & -0.162 & -0.174 \\
\hline & $(0.094)$ & $(0.110)$ & $(0.111)$ & $(0.096)$ & $(0.096)$ \\
\hline \multirow[t]{2}{*}{ Ln[Importer Auditing Stds] } & 0.055 & -0.013 & -0.012 & 0.112 & 0.117 \\
\hline & $(0.096)$ & $(0.113)$ & $(0.114)$ & $(0.097)$ & $(0.097)$ \\
\hline \multirow[t]{2}{*}{ Ln[Exporter Corruption] } & $-0.252^{*}$ & $-0.208 *$ & $-0.213^{*}$ & $-0.267^{*}$ & $-0.266^{*}$ \\
\hline & $(0.074)$ & $(0.086)$ & $(0.086)$ & $(0.077)$ & $(0.077)$ \\
\hline \multirow[t]{2}{*}{ Ln[Importer Corruption] } & 0.048 & 0.015 & 0.016 & 0.111 & 0.111 \\
\hline & $(0.065)$ & $(0.076)$ & $(0.076)$ & $(0.066)$ & $(0.066)$ \\
\hline \multirow[t]{2}{*}{ Regional Trade Agreement } & -0.060 & -0.070 & -0.067 & -0.039 & -0.042 \\
\hline & $(0.048)$ & $(0.053)$ & $(0.053)$ & $(0.048)$ & $(0.048)$ \\
\hline \multirow[t]{2}{*}{ WTO Members } & 0.069 & & & & \\
\hline & $(0.052)$ & & & & \\
\hline \multirow[t]{2}{*}{ Exporter Tax (\% GDP) } & & & 1.34 & & \\
\hline & & & $(0.76)$ & & \\
\hline \multirow[t]{2}{*}{ Importer Tax (\% GDP) } & & & 0.07 & & \\
\hline & & & $(0.74)$ & & \\
\hline \multirow[t]{2}{*}{ Exporter Inflation } & & & & & -0.20 \\
\hline & & & & & $(0.12)$ \\
\hline \multirow[t]{2}{*}{ Importer Inflation } & & & & & 0.13 \\
\hline & & & & & $(0.09)$ \\
\hline Year Dummies & Yes & Yes & Yes & Yes & Yes \\
\hline Bilateral Dummies & Yes & Yes & Yes & Yes & Yes \\
\hline Effect of Tariffs among RTA & & & 0055 & & - 109 \\
\hline Members & -0.431 & $0.06 /$ & 0.055 & -0.139 & -0.109 \\
\hline F-stat & 0.30 & 0.02 & 0.01 & 0.09 & 0.06 \\
\hline Observations & 86,185 & 64,429 & 64,429 & 83,735 & 83,735 \\
\hline R-squared & 0.57 & 0.56 & 0.56 & 0.57 & 0.57 \\
\hline
\end{tabular}

$* p<0.05$. Robust standard errors clustered on bilateral country pairs. 
Table 6: High- and Low-income Countries

Dep. var: $\ln V^{m}-\ln V^{x}$

(1)

(2)

(3)

\begin{tabular}{|c|c|c|c|}
\hline \multirow[t]{2}{*}{ Importer Tariff } & $-1.007 *$ & $-0.959 *$ & $-0.947 *$ \\
\hline & $(0.358)$ & $(0.352)$ & $(0.352)$ \\
\hline \multirow[t]{2}{*}{ Importer Tariff × RTA } & $1.051^{*}$ & 0.929 & 0.921 \\
\hline & $(0.484)$ & $(0.482)$ & $(0.481)$ \\
\hline \multirow[t]{2}{*}{ Importer Tariff $\times$ High Income Importer } & $-2.239 *$ & & \\
\hline & $(0.875)$ & & \\
\hline \multirow[t]{2}{*}{ Importer Tariff $\times$ High Inc. Importer $\times$ RTA } & 0.332 & & \\
\hline & $(1.200)$ & & \\
\hline \multirow[t]{2}{*}{ Ln[Port Quality] } & -0.025 & -0.025 & -0.025 \\
\hline & (0.039) & $(0.039)$ & $(0.039)$ \\
\hline \multirow[t]{2}{*}{ Ln[Exporter Auditing Stds] } & $-0.206^{*}$ & $-0.212^{*}$ & $-0.206 *$ \\
\hline & $(0.094)$ & $(0.095)$ & $(0.094)$ \\
\hline \multirow[t]{2}{*}{ Ln[Exporter Auditing Stds] $\times$ High Income } & & 0.019 & \\
\hline & & $(0.022)$ & \\
\hline \multirow[t]{2}{*}{ Ln[Importer Auditing Stds] } & 0.075 & 0.112 & 0.079 \\
\hline & $(0.095)$ & $(0.096)$ & $(0.096)$ \\
\hline \multirow[t]{2}{*}{ Ln[Importer Auditing Stds] $\times$ High Income } & & $-0.107^{*}$ & \\
\hline & & $(0.021)$ & \\
\hline \multirow[t]{2}{*}{ Ln[Exporter Corruption] } & $-0.253^{*}$ & $-0.257^{*}$ & $-0.258 *$ \\
\hline & $(0.074)$ & $(0.075)$ & $(0.076)$ \\
\hline \multirow[t]{2}{*}{ Ln[Exporter Corruption] $\times$ High Income } & & & 0.015 \\
\hline & & & $(0.021)$ \\
\hline \multirow[t]{2}{*}{ Ln[Importer Corruption] } & 0.061 & 0.096 & 0.118 \\
\hline & $(0.066)$ & $(0.066)$ & $(0.067)$ \\
\hline \multirow[t]{2}{*}{ Ln[Importer Corruption] $\times$ High Income } & & & $-0.109 *$ \\
\hline & & & $(0.022)$ \\
\hline \multirow[t]{2}{*}{ Regional Trade Agreement } & -0.065 & -0.053 & -0.052 \\
\hline & $(0.047)$ & $(0.048)$ & $(0.048)$ \\
\hline Year Dummies & Yes & Yes & Yes \\
\hline Bilateral Dummies & Yes & Yes & Yes \\
\hline Observations & 86,185 & 86,185 & 86,185 \\
\hline R-squared & 0.57 & 0.57 & 0.57 \\
\hline
\end{tabular}

$* p<0.05$. Robust standard errors, clustered on bilateral country pairs, in parentheses. 
Table 7:

Combined Effects for Low- and High-income Countries

\begin{tabular}{|c|c|c|c|}
\hline & (1) & (2) & (3) \\
\hline \multicolumn{4}{|l|}{ Lower-Income Countries } \\
\hline \multirow[t]{2}{*}{ Tariffs among non-RTA Members } & $-1.007^{*}$ & & \\
\hline & $(0.358)$ & & \\
\hline \multirow[t]{2}{*}{ Tariffs among RTA Members } & 0.044 & & \\
\hline & [0.010] & & \\
\hline \multirow[t]{2}{*}{ Exporter Auditing Stds } & & $-0.212^{*}$ & \\
\hline & & $(0.095)$ & \\
\hline \multirow[t]{2}{*}{ Importer Auditing Stds } & & 0.112 & \\
\hline & & $(0.096)$ & \\
\hline \multirow[t]{2}{*}{ Exporter Corruption } & & & $-0.258 *$ \\
\hline & & & $(0.076)$ \\
\hline \multirow[t]{2}{*}{ Importer Corruption } & & & 0.118 \\
\hline & & & $(0.067)$ \\
\hline \multicolumn{4}{|l|}{ High-Income Countries } \\
\hline \multirow[t]{2}{*}{ Tariffs among non-RTA Members ${ }^{a}$} & $-3.02 *$ & & \\
\hline & [13.53] & & \\
\hline \multirow[t]{2}{*}{ Tariffs among RTA Members ${ }^{a}$} & -1.86 & & \\
\hline & [2.89] & & \\
\hline \multirow[t]{2}{*}{ Exporter Auditing Stds } & & $-0.193 *$ & \\
\hline & & [4.18] & \\
\hline \multirow[t]{2}{*}{ Importer Auditing Stds } & & 0.005 & \\
\hline & & {$[0.001]$} & \\
\hline \multirow[t]{2}{*}{ Exporter Corruption } & & & $-0.243^{*}$ \\
\hline & & & [10.89] \\
\hline \multirow[t]{2}{*}{ Importer Corruption ${ }^{a}$} & & & 0.009 \\
\hline & & & {$[0.02]$} \\
\hline
\end{tabular}

$* p<0.05$. For coefficent estimates that come directly from Table 5 , standard errors are reported in parentheses. For coeffient estimates that require linear tests of multiple coeffiecients from Table 5, F-stats are reported in brackets. The $a$ superscript indicates that the high-income country estimate is statistically different from the lower-income country estimate. 


\section{Appendix Tables}

\section{Table A1:}

\section{Data dropped for missing observations and variables}

Total

Observations

\begin{tabular}{|c|c|c|c|}
\hline & Exporters & Importers & (11 years) \\
\hline Starting (2002-2012) & 178 & 178 & 346,566 \\
\hline $\begin{array}{l}\text { Drop observations where reported trade values are } \\
\text { missing for importer, exporter, or both }\end{array}$ & 178 & 178 & 165,215 \\
\hline $\begin{array}{l}\text { Drop observations with missing audit, tariff, ports, or } \\
\text { corruption data }\end{array}$ & 134 & 127 & 89,420 \\
\hline $\begin{array}{l}\text { Drop cases with too few (less than } 2 \text { ) observations to } \\
\text { identify country-pair fixed effects }\end{array}$ & 126 & 124 & 86,185 \\
\hline
\end{tabular}

\section{Table A2:}

Survey Questions Determining Proxy Variables from the Global Competitiveness Report

Variable

Port infrastructure quality

Strength of auditing and accounting standards

\section{Survey Question}

Port facilities and inland waterways in your country are ( $1=$ underdeveloped, 7 = as developed as the world's best)

Financial auditing and reporting standards regarding company's financial performance in your country are $1=$ extremely weak, 7 = extremely strong-the best in the world) 